\title{
PENGARUH KINERJA KEUANGAN TERHADAP PERTUMBUHAN LABA PADA PERUSAHAAN JASA TRANSPORTASI YANG TERDAFTAR DI BEI
}

\author{
Dyah Ratna Sari ${ }^{1}$, Dian Retnaningdiah ${ }^{2)^{*}}$ \\ ${ }^{1}$ Fakultas Ekonomi, Ilmu Sosial dan Humaniora, Universitas 'Aisyiyah Yogyakarta \\ e-mail: dyahratna24.dr@gmail.com \\ ${ }^{2}$ Fakultas Ekonomi, Ilmu Sosial dan Humaniora, Universitas 'Aisyiyah Yogyakarta \\ e-mail: dianretnaningdiah@unisayogya.ac.id
}

*Penulis Korespondensi

\begin{abstract}
In Indonesia, the development of the business world has become increasingly widespread which has resulted in increasingly fierce business competition. The performance of a company is assessed by using financial ratios. The purpose of this study is to determine the effect of financial performance on Profit Growth in Transportation Service Companies listed on the Indonesia Stock Exchange. This study employed a quantitative approach, the samples used were 4 transportation service companies listed on the Indonesia Stock Exchange, the data collection technique used was secondary data obtained from the company's website. The hypothesis testing shows that the current ratio has no significant effect on profit growth, which meansthat a high current ratio value may not necessarily increase company profits. The total asset turnover (TATO) has no significant effect on profit growth. This indicates that a high TATO means thatthe company only uses a few assets. The debt-to-equity ratio (DER) has a significant effect on profit growth.This shows that the higher the DER value, the riskier the company is. The net profit margin (NPM) has no significant effect on profit growth, which indicates that a high NPM value means the company can generate high net income as well.
\end{abstract}

Key words: Current Ratio, Total Asset Turnover, Debt to Equity Ratio and Net Profit Margin.

\section{PENDAHULUAN}

Di Indonesia perkembangan dunia usaha sudah semakin merebak luas yang mengakibatkan persaingan usaha yang semakin ketat, khususnya pada perusahaan jasa transportasi. Perusahaan jasa transportasi merupakan salah satu perusahaan yang tidak bisa dipisahkan dari kehidupan masyarakat luas. Karena kegiatan manusia yang mengharuskannya berpindah tempat, tentu saja sangat membutuhkan alat transportasi. Alat transportasi yang disediakan pun terdiri dari transportasi darat, laut dan udara. Di Indonesia terdapat 46 perusahaan jasa transportasi yang sudah terdaftar di Bursa Efek Indonesia (BEI).

Beberapa perusahaan jasa transportasi memiliki peningkatan layanan yang tepat sehingga menghasilkan kinerja keuangan yang sangat baik, namun tidak jarang juga

E-ISSN: 2777-1156

2021. Vol 5. No 2 
perusahaan jasa transportasi memiliki kinerja keuangan yang kurang baik. Menurut Mila dan Agung (2019) kinerja keuangan adalah salah satu metode analisis yang digunakan perusahaan untuk mengukur efektifitas dan kepatuhan dengan menggunakan aturan-aturan keuangan sebagai basis pelaksanaan keuangan yang baik dan benar. Kinerja keuangan yang baik akan menunjukan bahwa perusahaan dapat berjalan secara efektif dan efisien.

Dalam laporan keuangan, informasi yang paling penting yang dapat dilakukan untuk mengambil keputusan yaitu laba. Laba merupakan salah satu pengukuran aktivitas operasi dan dihitung berdasarkan atas dasar akuntansi akrual (Natalia, 2020). Dengan adanya laba ini, maka kinerja keuangan perusahaan dapat terlihat ketika sedang mengalami kenaikan atau sedang mengalami penurunan.

Untuk menentukan atau mengukur seberapa baik kinerja pada perusahaan salah satunya dengan menggunakan Rasio Keuangan. Rasio keuangan merupakan kegiatan membandingkan angka-angka yang ada dalam laporan keuangan dengan cara membagi satu angka dengan angka lainnya (Septian, 2016).

\section{TINJAUANPUSTAKA DAN PENGEMBANGAN HIPOTESIS}

\section{Kinerja Keuangan}

Kinerja keuangan adalah suatu usaha yang sangat penting dan formal bagi perusahaan untuk mengukur keberhasilan dalam menghasilkan laba, dan mengukur potensi perkembangan baik perusahaan melalui sumberdaya yang ada dan juga melalui kinerja perusahaan ini dapat digunakan untuk melihat potensi perusahaan dimasa yang akan datang (Reza dan Bambang, 2019). Mila dan Agung (2019) menyebutkan bahwa kinerja keuangan adalah salah satu metode analisis yang digunakan perusahaan untuk mengukur efektifitas dan kepatuhan dengan menggunakan aturan-aturan keuangan sebagai basis pelaksanaan keuangan yang baik dan benar. Kinerja keuangan bertujuan untuk tingkat rentabilitas, tingkat stabiltas, tingka tlikuiditas dan tingkat solvabilitas.

\section{Laba}

Dalam suatu perusahaan memiliki usaha untuk meningkatkan laba yang ada pada perusahaan, karena suatu perusahaan dapat dikatakan baik ketika melihat adanya kenaikan laba dalam perusahaannya. Pengertian dari laba sendiri yaitu merupakan salah satu pengukuran aktivitas operasi dan dihitung berdasarkan atas dasar akuntansi akrual (Natalia, 2020). Jenis laba menurut Budi, 2020 terdiri atas Laba Kotor (gross profit), Laba Operasi (operating profit), Laba Bersih (net profit). Laba kotor (gross profit) artinya laba yang diperoleh sebelum dikurangi biaya-biaya yang menjadi beban perusahaan. Artinya laba keseluruhan yang pertama sekali perusahaan peroleh.Laba Operasi (operating profit) merupakan nilai yang tersisa setelah semua biaya operasi dikurangi dari pendapatan. Laba bersih (net profit) merupakan laba yang telah dikurangi biaya-biaya yang merupakan beban perusahaan dalam suatu periode tertentu termasuk pajak.

\section{E-ISSN: 2777-1156}

2021. Vol 5. No 2 


\section{RasioKeuangan}

Rasio keuangan digunakan untuk menentukan atau mengukur seberapa baik kinerja pada perusahaan salah satunya dengan menggunakan Rasio Keuangan. Rasio keuangan merupakan kegiatan membandingkan angka-angka yang ada dalam laporan keuangan dengan cara membagi satu angka dengan angka lainnya (Septian, 2016). Rasio keuangan meliputi rasio likuiditas, rasio lancar, rasio solvabilitas, rasio aktivitas dan rasio profitabilitas. Rasio likuiditas adalah rasio yang menunjukkan kemampuan perusahaan dalam membayar utangutang jangka pendeknya yang jatuh tempo atau rasio untuk mengetahui kemampuan perusahaan dalam membiayai dan memenuhi kewajiban pada saat ditagih (Solikhah, Susyanti dan Wahono 2016); Rasio Lancar (Current Ratio) merupakan rasio untuk mengukur kemampuan perusahaan dalam membayar kewajiban jangka pendek atau utang yang segera jatuh tempo pada saat ditagih secara keseluruhan" (Solikhah, Susyanti dan Wahono 2016); Rasio Solvabilitas adalah rasio yang mengukur sejauh mana pembelanjaan dilakukan oleh hutang yang dibandingkan dengan modal, dan kemampuan untuk membayar bunga dan beban tetap lain (Mahaputra 2012); RasioAktivitas digunakan untuk mengukur tingkat efisiensi pemanfaatan sumber daya perusahaan (penjualan, persediaan, penagihan piutang, danlainnya) atau rasio untuk menilai kemampuan perusahaan dalam melaksanakan aktivitas seharihari;Rasio profitabilitas yakni Rasio yang menilai kemampuan perusahaan dalam mencari keuntungan." Rasio ini dapat juga memberikan ukuran tingkat efektivitas manajemen suatu perusahaan. Hal ini ditunjukkan oleh adanya laba yang dihasilkan dari penjuaan dan pendapatan investasi. Inti dari penggunaan rasio ini adalah untuk menunjukkan efisiensi perusahaan (Mahaputra, 2012).

\section{KerangkaKonsep}

Kerangka konsep dalam penelitian ini adalah sebagaimana terlihat pada gambar 1 .

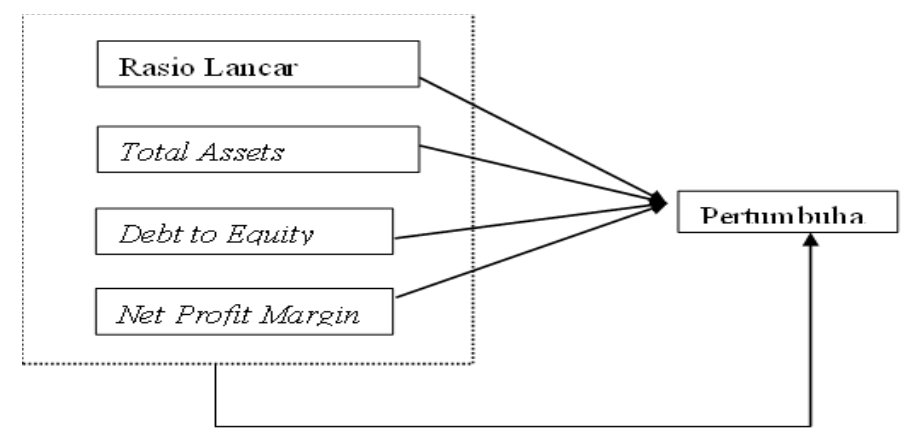

Gambar 1. Kerangka Konsep

\section{E-ISSN: 2777-1156}




\section{HIPOTESIS}

Berdasarkan pada kerangka konsep tersebut, maka hipotesis yang dapat diambil dalam penelitian ini adalah sebagai berikut:

H1: Current Ratio berpengaruh signifikan terhadap pertumbuhan laba

H2: Total Assets Turnover berpengaruh signifikan terhadap pertumbuhan laba

H3: Debt to Equity Ratio berpengaruh signifikan terhadap pertumbuhan laba

H4: Net Profit Margin berpengaruh signifikan terhadap pertumbuhan laba

H5: CR, TATO, DER dan NPM secara bersama-sama berpengaruh signifikan terhadap pertumbuhan laba.

\section{METODE PENELITIAN}

\section{Rancangan Penelitian}

Pendekatan penelitian yang dilakukan dalam penelitian ini adalah penelitian kuantitatif, penelitian kausal komparatif. Dimana penelitian kausal komparatif adalah penelitian yang menunjukkan arah hubungan antara variabel bebas dengan variabel terikat. Dalam penelitian ini bertujuan untuk mengetahui pengaruh variabel independen (current ratio, total asset turnover, debt to equity ratio dan net profit margin) terhadap variabel dependen (pertumbuhan laba).

\section{Pengumpulan Data}

Populasidan Sampel

Populasi yang digunakan dalam penelitian ini adalah perusahaan jasa transportasi yang terdaftar di Bursa Efek Indonesia.Pemilihan sampel ditentukan secarapurposive sampling dengan tujuan untuk mendapatkan sampel yang sesuai dengan kriteria yang ditentukan. Kriteria untuk dipilih menjadi sampel adalah perusahaan jasa transportasi udara yang terdaftar di Bursa Efek Indonesia dan perusahaan jasa trasnportasi udara yang terdaftar di BEI dan mempublikasikan laporan tahunan dari 2015-2019.

Dalam melakukan pengukuran kinerja, penelitian ini menggunakan beberapa rasio keuangan seperti Current Ratio (CR), Total Asset Turnover (TATO), Debt to Equity Ratio (DER) dan Net Profit Margin (NPM) untuk mengetahui apakah pertumbuhan laba dapat dipengaruhi atau tidak.

\section{Variabel yang diamati}

Dalam penelitian ini menggunakan duavariabel, yaitu variable bebas dan variable terikat. Variabel bebas (Variabel $\mathrm{X}$ ) adalah variabel yang sifatnya mempengaruhi variable terikat (Variabel Y) dimana dalam penelitian ini menggunakan variable bebas yaitu kinerja keuangan, sedangkan variable terikatnya adalah pertumbuhan laba.

E-ISSN: 2777-1156

2021. Vol 5. No 2 
Variabel Bebas

a. Rasio Lancar (Current Ratio)

Rasio Lancar atau current ratio merupakan rasio untuk mengukur kemampuan perusahaan dalam membayar kewajiban jangka pendek atau utang yang segera jatuh tempo pada saat ditagih secara keseluruhan (Solikhah, Susyanti dan Wahono (2016)).

$$
\text { Current Ratio }=\frac{\text { AktivaLancar }}{\text { Utang Lancar }} \times 100 \%
$$

b. Total Assets Turnover (TATO)

Total Assets Turnover menunjukkan efektivitas perusahaan dalam menggunakan asetnya untuk menghasilkan pendapatan.

$$
\text { TATO }=\frac{\text { PenjualanBersih }}{\text { Total Aktiva }}
$$

c. Debt to Equity Ratio (DER)

Debt to Equity Ratio menunjukkan perbandingan antara utang dan ekuitas perusahaan.

$$
\text { Debt to Equity Ratio }=\frac{\text { Total Kewajiban }}{\text { Total Ekuitas }}
$$

d. Net Profit Margin (NPM)

Net Profit Margin mencerminkan kemampuan perusahaan dalam menghasilkan laba neto dari setiap penjualannya.

$$
N P M=\frac{\text { LabaBersih Setelah Pajak }}{\text { Total Penjualan }}
$$

Variabel Terikat

Dalam penelitian ini pertumbuhan laba merupakan variabel terikat. Pertumbuhan laba adalah perubahan presentase kenaikan laba yang diperoleh oleh suatu perusahaan.

\section{Analisis Regresi Berganda}

Analisis regresi berganda yaitu suatu analisis yang menguji pengaruh Current Ratio, Total Assets Turnover, Debt to Equity Ratio, dan Net Profit Margin terhadap Pertumbuhan Laba, dengan menggunakan rumus Prawoto dan Basuki, (2016:74) sebagai berikut :

$$
\mathrm{Y}=\mathrm{b} 0+\mathrm{b} 1 \mathrm{X} 1+\mathrm{b} 2 \mathrm{X} 2+\mathrm{b} 3 \mathrm{X} 3+\mathrm{b} 4 \mathrm{X} 4+\mathrm{e}
$$

\section{E-ISSN: 2777-1156}

2021. Vol 5. No 2 
Keterangan:

$\mathrm{Y}=$ Pertumbuhan Laba

$\mathrm{X} 1=$ Current Ratio

$\mathrm{X} 2=$ Total Assets Turnover

$\mathrm{X} 3$ = Debt to Equity Ratio

$\mathrm{X} 4=$ Net Profit Margin

\section{Uji Regresi Berganda}

Dalam penelitian ini menggunakan uji regresi linear berganda untuk mengetahui apakah Current Ratio, Total Assets Turnover, Debt to Equity Ratio, dan Net Profit Margin memiliki pengaruh terhadap pertumbuhan laba. Menurut (Rahayu, 2015) uji statistik t pada dasarnya menunjukkan seberapa jauh pengaruh satu variabel independen secara individual dalam menerangkan variabel dependen.

\section{HASIL DAN PEMBAHASAN}

\section{HASIL}

A.Statistik Deskriptif

1. Current Ratio (X1) yaitu memiliki nilai minimum sebesar 0,16 dan nilai maximum sebesar 2,23 dengan hasil rata-rata (mean) sebesar 0,8111 dan standar deviasi sebesar 0,58960. Nilai minimum terjadi pada perusahaan Air Asia pada tahun 2018 hal ini menunjukkan bahwa pada tahun 2018 Air Asia memiliki nilai Current Ratio yang lebih kecil dibandingkan dengan perusahaan lainnya. Sedangkan nilai maximum terjadi pada perusahaan CAS Group pada tahun 2015 hal ini menunjukan bahwa pada tahun 2015 perusahaan CAS Group memiliki nilai Current Ratio yang lebih tinggi dibandingkan perusahaan lainnya.

2. Hasil analisis statistic deskriptif variable Total Asset Turnover (X2) menunjukkan nilai minimum yaitu 0,16 dan nilai maximum 2,57 dengan nilai rata-rata (mean) sebesar 0,9363 dan standar deviation sebesar 0,58011. Nilai minimum terjadi pada perusahaan Indonesia Air pada tahun 2015 hal ini menunjukkan bahwa pada tahun 2015 Indonesia Air memiliki nilai Total Asset Turnover yang lebih kecil dibandingkan perusahaan lainnya. Sedangkan nilai maximum terjadi pada perusahaan Air Asia pada tahun 2019 hal ini menunjukkan bahwa pada tahun 2019 Air Asia memiliki nilai Total Asset Turnover yang lebih tinggi dari pada perusahaan lainnya.

3. Hasil analisis statistic deskriptif pada variable Debt to Equity Ratio (X3) menunjukkan nilai minimum sebesar $-4,55$ dan nilai maximum sebesar 82,38 dengan nilai rata-rata (mean) sebesar 6,3768 dan standar deviation sebesar 18,14791. Nilai minimum terjadi pada perusahaan Air Asia tahun 2018 hal ini menunjukkan bahwa tahun 2018 Air Asia memiliki nilai Debt to Equity Ratio yang lebih kecil dibandingkan dengan perusahaan lainnya. Sedangkan nilai maximum terjadi pada perusahaan Air Asia tahun 2017 hal ini menunjukkan bahwa pada tahun 2017 Air Asia memiliki nilai Debt to Equity Ratio yang lebih tinggi dibandingkan dengan perusahaan lainnya.

4. Hasil analisis statistic deskriptif pada variable Net Profit Margin (X4) menunjukkan nilai minimum sebesar $-67,55$ dan nilai maximum 17,99 dengannilai rata-rata yaitu $-11,4417$

E-ISSN: 2777-1156

2021. Vol 5. No 2 
dan nilai standar deviation sebesar 25,03769. Nilai minimum terjadi pada perusahaan Indonesia Air tahun 2016 hal ini menunjukkan bahwa pada tahun 2016 perusahaan Indonesia Air memiliki nilai Net Profit Margin yang lebih kecil daripada perusahaan lainnya. Sedangkan nilai maximum terjadi pada perusahaan CAS Group tahun 2015 hal ini menunjukkan bahwa pada tahun 2015 perusahaan CAS Group memiliki nilai Net Profit Margin yang lebih tinggi daripada perusahaan lainnya.

5. Hasil analisis statistik deskriptif pada variabel pertumbuhanlaba (Y) memiliki hasil uji statistik deskriptif dengan nilai minimum yaitu -23,79 dan nilai maximum yaitu 23,40 dengan nilai rata-rata (mean) yaitu $-0,3605$ dan nilai standar deviation sebesar 7,69814. Nilai minimum terjadi pada perusahaan Garuda Indonesia tahun 2017 hal ini menunjukkan bahwa pada tahun 2017 Garuda Indonesia memiliki pertumbuhan laba yang lebih kecil dibandingkan dengan perusahaan lainnya. Sedangkan nilai maximum terjadi pada perusahaan Air Asia tahun 2017 hal ini menunjukkan bahwa pada tahun 2017 Garuda Indonesia memiliki pertumbuhan laba yang lebih tinggi dibandingkan dengan perusahaan lainnya.

B. Uji Asumsi Klasik

1. Uji Normalitas

Tabel 1. Hasil Uji Normalitas Kolmogorov-Smirnov (K-S) Setelah Transformasi Data One-Sample Kolmogorov-Smirnov Test

\begin{tabular}{l|r} 
Asymp. Sig. &, 107
\end{tabular}

(2-tailed)

Sumber: Hasil olah data SPSS.

Berdasarkan hasil Uji Normalitas Kolmogorov-Smirnov(K-S) mendapatkan hasil nilai signifikan yaitu 0,107. Dimana hasil tersebut lebih besar dari 0,05. Maka dapat disimpulkan bahwa hasil Uji Normalitas Kolmogorov-Smirnov berdistribusi normal.

2. Uji Multikolinearitas

Berdasarkan hasil uji multikolinearitas menunjukkan bahwa variable Current Ratio (X1) memiliki nilai tolerance 0,644. Lalu pada variabel Total Asset Turnover (X2) memiliki nilai tolerance sebesar 0,531. Sementara pada variable Debt to Equity Ratio (X3) memiliki nilai tolerance sebesar 0,901. Dan pada variable Net Profit Margin (X4) memiliki nilai tolerance yaitu 0,415 atau dapat dikatakan bahwa semua variabel independent dalam penelitian ini mempunyai Nilai Tolerance $\geq 0,10$ dan nilai Variance Inflation Factor (VIF) $\leq 10$. Jadi, dapatdisimpulkan bahwa pada penelitian ini tidak terjadi multikolinearitas.

\section{Uji Autokorelasi}

Berdasarkan hasil uji autokorelasi menunjukkan bahwa nilai Durbin-Watson yaitu 2,154. Berdasarkan tabel DW diketahui bahwa nilai DU yaitu 1,8283. Sedangkan dari hasil pengujian diatas memiliki hasil DW yaitu 2,154. Maka, dapat disimpulkan bahwa dalam penelitian ini tidak terjadi autokorelasi.

E-ISSN: 2777-1156

2021. Vol 5. No 2 
4. Regresi Linear Berganda

Hasil persamaan regresi linear berganda dalam penelitian ini dapat diketahui dari table hasil uji coefficients berdasarkan output SPSS dan dapat dijelaskan dalam persamaan regresi sebagai berikut:

$$
\mathrm{PL}=-5,845+3,200 \mathrm{CR}-0,051 \mathrm{TATO}+0,324 \mathrm{DER}-0,076 \mathrm{NPM}+\mathrm{e}
$$

$\begin{array}{ll}\text { Keterangan : } \\ \text { PL } & =\text { Pertumbuhan Laba } \\ \text { CR } & =\text { Current Ratio } \\ \text { TATO } & =\text { Total Asset Turnover } \\ \text { DER } & =\text { Debt to Equity Ratio } \\ \text { NPM } & =\text { Net Profit Margin } \\ \mathrm{e} & =\text { Error }\end{array}$

5. Uji Heteroskedastisitas

Tabel 2. Hasil Uji Heteroskedastisitas Coefficients $^{\mathrm{a}}$

\begin{tabular}{|l|l|l|}
\hline Model & T & Sig. \\
\hline (Constant) & 1,173 &, 259 \\
\hline X1_CR & $-1,231$ &, 237 \\
\hline X2_TATO &, 186 &, 855 \\
\hline X3_DER &,- 811 &, 430 \\
\hline X4_NPM &, 506 &, 620 \\
\hline
\end{tabular}

a. Dependent Variabel: ABRESID. Sumber: Hasil olah data SPSS.

Berdasarkan hasil pengujian heteroskedastisitas diatas. Semua variabel $X$ pada penelitian ini memiliki hasil nilai sig yaitu $\geq 0,05$, maka pengujian heteroskedastisitas dalam penelitian ini dapat dikatakan normal atau tidak bermasalah.

E-ISSN: 2777-1156

2021. Vol 5. No 2 
C. Uji Hipotesis (Uji t)

\section{Tabel 3. Uji Hipotesis (Uji t) \\ Coefficients ${ }^{\mathrm{a}}$}

\begin{tabular}{|l|l|l|}
\hline Model & T & Sig. \\
\hline (Constant) & $-1,129$ &, 277 \\
\hline X1_CR & 1,135 &, 274 \\
\hline X2_TATO &,- 016 &, 987 \\
\hline X3_DER & 4,187 &, 001 \\
\hline X4_NPM &,- 918 &, 373 \\
\hline
\end{tabular}

a. Dependent Variable: Y_PertumbuhanLaba

Sumber: Hasil olah data SPSS.

Berdasarkan hasil uji t, variabel Current Ratio (X1) memiliki nilai signifikan yaitu 0,274 atau memiliki nilai lebih dari 0,05 sehingga tidak ada pengaruh secara parsial. Lalu pada variableTotal Asset Turnover (X2) memiliki nilai signifikan sebesar 0,987 yang berarti lebih besar dari 0,05 sehingga TATO tidak berpengaruh secara parsial. Sementara pada Debt to Equity Ratio (X3) memiliki nilai signifikan yaitu 0,001 yang berarti kurang dari 0,05 sehingga Debt to Equity berpengaruh secara parsial. Dan Net Profit Margin (X4) memiliki nilai signifikan yaitu 0,373 yang berarti lebih besar dari 0,05 sehingga Net Profit Margin tidak berpengaruh secara parsial. Maka, dapat disimpulkan bahwa dari keseluruhan nilai $\mathrm{X}$ hanya $D E R$ (X3) yang berpengaruh signifikan terhadap pertumbuhan laba. Dikarenakan memiliki nilai sig $\leq 0,05$.

D. Uji F

$\begin{array}{r}\text { Tabel 4. Hasil Uji F } \\
\text { ANOVA }\end{array}$
\begin{tabular}{|l|l|}
\hline F & Sig. \\
\hline 4,571 &, $013^{\mathrm{b}}$ \\
\hline
\end{tabular}

Sumber: Hasil olah data SPSS.

Berdasarkan pengujian diatas dapat dilihat hasil uji $\mathrm{F}$ dimana hasil tersebut memiliki nilai signifikan yaitu 0,013 yang berarti lebih kecil dari 0,05 sehingga menunjukkan bahwa seluruh variabel in dependen secara simultan berpengaruh terhadap variabel dependen. Maka, dapat dikatakan bahwa Current Ratio, Total Asset Turnover, Debt to Equity Ratio dan Net Profit Margin secara bersama-sama (simultan) berpengaruh terhadap Pertumbuhan Laba. 
E. Koefisien Determinasi $\left(\mathrm{R}^{2}\right)$

Tabel 5. Hasil Uji KoefisienDeterminasi $\left(\mathbf{R}^{2}\right)$ Model Summary ${ }^{\mathrm{b}}$

\begin{tabular}{|l|l|l|l|}
\hline Model & R & R Square & $\begin{array}{l}\text { Adjusted R } \\
\text { Square }\end{array}$ \\
\hline 1 &, $741^{\mathrm{a}}$ &, 549 &, 429 \\
\hline
\end{tabular}

Sumber: Hasil olah data SPSS.

Berdasarkan pengujian Koefisien Determinasi diatas, diketahui nilai dari Adjusted $R$ Square yaitu 0,429. Hal ini menunjukkan bahwa presentase pengaruh variable independen (Current Ratio, Total Asset Turnover, Debt to Equity Ratio dan Net Profit Margin) adalah sebesar $42,9 \%$. Maka, dapat disimpulkan bahwa variabel yang digunakan dalam model penelitian ini mampu menjelaskan sebesar $42,9 \%$ terhadap variable dependennya, sedangkan sisanya dijelaskan oleh variabel lain diluar model.

\section{PEMBAHASAN}

a. Pengaruh Current Ratio terhadap Pertumbuhan Laba

Dalam uji t yang telah dilakukan menunjukan bahwa pengaruh Current Ratio terhadap pertumbuhan laba mendapatkan hasil nilai signifikan yaitu 0,274. Dengan demikian pengaruh Current Ratio dapat dikatakan berpengaruh tidak signifikan terhadap pertumbuhan laba, dikarenakan nilai signifikan yang didapatkan $\geq 0,05$. Hal tersebut didukung dengan hasil penelitian yang dilakukan oleh Intan Permatasari (2016) yang menyatakan bahwaCurrent Ratio berpengaruh tidak signifikan.

b. Pengaruh Total Asset Turnover terhadap Pertumbuhan Laba

Dalam uji t yang telah dilakukan menunjukan bahwa pengaruh Total Asset Turnover terhadap pertumbuhan laba mendapatkan hasil nilai signifikan 0,987. Dengan demikian pengaruh Total Asset Turnover dapat dikatakan berpengaruh tidak signifikan terhadap pertumbuhan laba, dikarenakan nilai signifikan yang didapatkan $\geq 0,05$. Hal ini didukung dengan hasil penelitian yang dilakukan oleh Intan Permatasari (2016) yang menyatakan bahwa Total Asset Turnover berpengaruh tidak signifikan.

c. Pengaruh Debt to Equity Ratio terhadap Pertumbuhan Laba

Dalam uji t yang telah dilakukan menunjukkan bahwa pengaruh Debt to Equity Ratio terhadap pertumbuhan laba mendapatkan hasil nilai signifikan yaitu 0,001. Dengan demikian pengaruh Debt to Equity Ratio dapat dikatakan berpengaruh signifikan terhadap pertumbuhan laba, dikarenakan memiliki nilai signifikan $\leq 0,05$. Hal ini didukung oleh penelitian yang dilakukan oleh Septian (2016) yang menyatakan bahwa Debt to Equity Ratio berpengaruh signifikan.

E-ISSN: 2777-1156 
d. Pengaruh Net Profit Margin terhadap Pertumbuhan Laba

Dalam uji t yang telah dilakukan menunjukkan bahwa pengaruh Net Profit Margin terhadap pertumbuhan laba mendapatkan hasil nilai signifikan yaitu 0,373. Dengan demikian pengaruh Net Profit Margin dapat dikatakan berpengaruh tidak signifikan terhadap pertumbuhan laba, dikarenakan memiliki nilai signifikan $\geq 0,05$. Hal ini didukung oleh penelitian yang dilakukan oleh Dewi Pramita (2015) yang menyatakan bahwa Net Profit Margin berpengaruh tidak signifikan.

e. Pengaruh Current Ratio, Total Asset Turnover, Debt to Equity Ratio dan Net Profit Margin secara simultan terhadap Pertumbuhan Laba

Dalam pengujian Koefisien Determinasi yang telah dilakukan maka dapat disimpulkan bahwa pengaruh Current Ratio, Total Asset Turnover, Debt to Equity Ratio, dan Net Profit Margin secara bersama-sama (simultan) berpengaruh terhadap pertumbuhan laba sebesar $42,9 \%$.

\section{KESIMPULAN}

Penelitian ini digunakan untuk mengetahui variable independen yang terdiri dari Current Ratio, Total Asset Turnover, Debt to Equity Ratio dan Net Profit Margin terhadap variable dependen yaitu Pertumbuhan Laba pada Perusahaan Jasa Transformasi yang terdaftar di Bursa Efek Indonesia (BEI) periode 2015-2019. Berdasarkan hasil penelitian maka dapat diambil kesimpulan sebagai berikut:

1. Current Ratio berpengaruh tidak signifikan terhadap pertumbuhan laba. Hal ini menunjukkan bahwa nilai current ratio yang tinggi belum tentu dapat meningkatkan laba perusahaan.

2. Total Asset Turnover berpengaruh tidak significan terhadap pertumbuhan laba. Hal ini menjelaskan bahwa TATO yang tinggi memiliki arti bahwa perusahaanhanya menggunakan sedikit asset atau aset yang digunakan pada perusahaan sudah usang.

3. Debt to Equity Ratio berpengaruh signifikan terhadap pertumbuhan laba. Hal ini menunjukkan bahwa utang memberikan dampak terhadap kelangsungan hidupperusahaan, terutama dalam meningkatkan laba. Maka dari itu dikatakan semakin tinggi nilai $D E R$ maka perusahaan semakin beresiko.

4. Net Profit Margin berpengaruh tidak signifikan terhadap pertumbuhan laba. Hal ini menunjukkan bahwa nilai net profit margin yang tinggi maka perusahaan dapat menghasilkan laba bersih yang tinggi pula. Dengan demikian pertumbuhan laba akan meningkat.

\section{SARAN}

Berdasarkan hasil penelitian bahwa variabel Current Ratio, Total Asset Turnover, Debt to Equity Ratio dan Net Profit Margin berpengaruh sebesar 42,9\% terhadap Pertumbuhan Laba pada Perusahaan Jasa Transportasi yang terdaftar di Bursa Efek Indonesia. Beberapa saran yang dapat disampaikan yaitu bahwa perusahaan dapat lebih mengefektifkan dan mengefisienkan penggunaan biaya operasional, dan biaya pengeluaran lainnya sehingga dapat

E-ISSN: 2777-1156 
meningkatkan penjualan dan dapat mencapai laba yang diinginkan. Penelitian selanjutnya sebaiknya lebih memperluas sampel dan meningkatkan atau menambah variabel yang belum diikutkan dalam model seperti quick ratio, inventory turnover, debt to asset ratio dan return on investment sabagai faktor yang mempengaruhi pertumbuhan laba.

\section{REFERENSI}

Adisetiawan, R. (2012). Analisis Pengaruh Kinerja Keuangan dalam Memprediksi. Jurnal Aplikasi Manajemen .

Bosnia, T. (2018, April 03). Rugi AirAsia Indonesia Membengkak Jadi Rp. 512 M. Retrieved Maret 28, 2021, from CNBC Indonesia: https://www.cnbcindonesia.com/market/20180403152347-17-9527/rugi-airasia-indonesiamembengkak-jadi-rp-512-m

Djannah, R. (2017). PENGARUH KINERJA KEUANGAN TERHADAP PERTUMBUHAN LABA PADA PERUSAHAAN FOOD AND BEVERAGES. Jurnal Ilmu dan Riset Manajemen .

Heze, E. (2020). Perusahaan Transportasi yang Terdaftar di BEI. Retrieved Maret 27, 2021, from Saham Gain: https://www.sahamgain.com/2020/11/perusahaan-transportasi-yangterdaftar.html

Kho, B. (2020, Agustus 12). Pengertian Laba atau Profit dan Jenis-jenis Laba. Retrieved Juni 25, 2021, from Ilmu Manajemen Industri: https://ilmumanajemenindustri.com/pengertian-laba-atau-profit-jenis-jenis-laba-keuntungan/

Kinerja Garuda Merosot, Berikut Penjelasan APG Dan Sekarga. (2018, Januari 23). Retrieved Maret 28, 2021, from Bisnis News: https://bisnisnews.id/detail/berita/kinerjagaruda-merosot-berikut-penjelasan-apg-dan-sekarga

Lutfi, A. M., \& Sunardi, N. (2019). PENGARUH CURRENT RATIO (CR), RETURN ON EQUITY (ROE),. Jurnal Sekuritas (Saham, Ekonomi, Keuangan, dan Investasi) .

Pendidikan, D. (2021, Mei 27). Kinerja Keuangan - Pengertian Menurut Para Ahli, Pengukuran, Tujuan, Analisis, Rasio \& Penilaian. Retrieved Juni 25, 2021, from Dosen Pendidikan: https://www.dosenpendidikan.co.id/kinerja-keuangan/

Paranoan, N. (2020). MaknaLabaBagiPelakuBisnisWaralaba. E-JurnalAkuntansi .

Nilayanti, M., \& Suaryana, A. (2019). Pengaruh Kepemilikan Manajerial dan Kepemilikan Institusional Terhadap Kinerja Keuangan Perusahaan Dengan Kebijakan Deviden Sebagai Pemoderasi. E-Jurnal Akuntansi Universitas Udayana .

Solikhah, M., Susyanti, J., \& Wahono, B. (2016). ANALISA KINERJA KEUANGAN PERUSAHAAN REAL ESTATE DAN PROPERTY SEBELUM DAN SELAMA DIBERLAKUKANNYA PP NO.34 TAHUN 2016. $e$-Jurnal Riset Manajemen .

E-ISSN: 2777-1156

2021. Vol 5. No 2 
Mahaputra, N. K. (2012). PENGARUH RASIO-RASIO KEUANGAN TERHADAP PERTUMBUHAN LABA PADA PERUSAHAAN MANUFAKTUR YANG TERDAFTAR DI BEI. Jurnal Akuntansi \& Bisnis .

Pradita, R. A., \& Suryono, B. (2019). PENGARUH KINERJA KEUANGAN TERHADAP NILAI PERUSAHAAN DENGAN PENGUNGKAPAN CORPORATE SOCIAL RESPONSIBILITY SEBAGAI VARIABEL MODERASI. Jurnal Ilmu dan Riset Akuntansi .

Basuki, A. T., \& Prawoto, N. (2016). ANALISIS REGRESI DALAM PENELITIAN EKONOMI \& BISNIS. Depok: Rajawali Pers.

Rahayu. (2015). Pengaruh Perputaran Piutang dan Perputaran Kas Terhadap Tingkat Likuiditas. 